\title{
ANALISIS PENGARUH LAJU PUTAR TERHADAP KOROSI BAJA KARBON API 5LX65 MENGGUNAKAN METODE ELECTROCHEMICAL IMPEDANCE SPECTROSCOPY
}

\section{ANALYSIS OF ROTATION SPEED EFFECT ON API 5LX65 CARBON STEEL CORROSION USING ELECTROCHEMICAL IMPEDANCE SPECTROSCOPY}

\author{
Agus Solehudin ${ }^{1}$ dan Asep Lukman $K^{2}$ \\ ${ }^{1}$ Teknik Mesin, FPTK - UPI, Jl. Dr. Setiabudi 229 Bandung \\ ${ }^{2}$ Balai Besar Bahan dan Barang Teknik (B4T), Jl. Sangkuriang 14 Bandung \\ Email : aseplukmank@yahoo.com
}

Diterima : 16 April 2012

Direvisi : 14 Mei 2012

Disetujui : 13 Juni 2012

\begin{abstract}
ABSTRAK
Pada percobaan ini, telah dipelajari pengaruh laju putar terhadap laju korosi baja karbon API 5LX65 yang direndam selama 24 jam dalam larutan $\mathrm{NaCl} \mathrm{3,5 \%}+500 \mathrm{mg} / \mathrm{L} \mathrm{H}_{2} \mathrm{~S}$ menggunakan metode EIS (Electrochemical Impedance Spectroscopy) pada suhu $50{ }^{\circ} \mathrm{C}$ dan $\mathrm{pH} 4$ dengan variasi laju putar $50 \mathrm{rpm}, 150$ rpm, dan $250 \mathrm{rpm}$. Hasil percobaan memperlihatkan pergeseran dan penyempitan kurva setengah lingkaran impedansi imaginer terhadap impedansi real, dengan meningkatnya laju putar dari 50 rpm sampai dengan 250 rpm. Hal ini mengindikasikan bahwa aktifitas pelarutan baja meningkat dengan percepatan laju putar. Nilai $C_{d l}$ meningkat dengan meningkatnya laju putar. Nilai tahanan polarisasi $\left(R_{p}\right)$ semakin menurun dengan meningkatnya laju putar, sementara nilai tahanan larutan $\left(R_{s}\right)$ relatif tidak berubah. Potensial korosi pada laju putar $50 \mathrm{rpm}, 150 \mathrm{rpm}$ dan $250 \mathrm{rpm}$ stabil pada $-517 \mathrm{mV}$ hingga $-508 \mathrm{mV}$ terhadap Ag/AgCl. Gabungan pengamatan Scanning Electron Microscope (SEM), Energy Dispersive Spectroscopy (EDS) dan X-Ray Diffractomer $(X R D)$ menunjukkan terbentuknya lapisan produk korosi. Hasil analisis XRD specimen uji yang dikorosikan pada suhu $50{ }^{\circ} \mathrm{C}$ selama 24 jam menunjukkan bahwa lapisan produk korosi mengandung besi sulfida (FeS). Morfologi permukaan specimen ini memperlihatkan adanya korosi sumuran.
\end{abstract}

Kata kunci: laju putar, korosi, baja karbon, EIS, $\mathrm{H}_{2} \mathrm{~S}$

\section{ABSTRACT}

In this experiment the influence of rotation speed on corrosion rate of API 5LX65 carbon steel in 3.5\% $\mathrm{NaCl}$ solution containing $500 \mathrm{mg} / \mathrm{L} \mathrm{H}_{2} \mathrm{~S}$ at a temperature of $50{ }^{\circ} \mathrm{C}$ and $\mathrm{pH} 4$ during 24 hours have been studied by using EIS (Electrochemical Impedance Spectroscopy) method. The experimental results of carbon steel corrosion in 3.5\% NaCl solution containing $500 \mathrm{mg} / \mathrm{L} \mathrm{H}_{2} \mathrm{~S}$ at $50 \mathrm{rpm}, 150 \mathrm{rpm}$, and $200 \mathrm{rpm}$ showed a shift and narrowing of the imaginary impedance semi circle curve against real impedance, with increasing rotation speed of $50 \mathrm{rpm}$ to $250 \mathrm{rpm}$. This indicates that the activity of the steel dissolution increased with the acceleration of rotation speed. The value of $C_{d l}$ increases with increasing the rotation speed. Value of polarization resistance (Rp) decreased with the increasing the rotating speed, while the value of the solution resistance (Rs) remained relatively unchanged. The corrosion potential at $50 \mathrm{rpm}, 150 \mathrm{rpm}$ and $250 \mathrm{rpm}$ showed steady at $-517 \mathrm{mV}$ to $-508 \mathrm{mV}$ vs Ag/AgCl. Combined observation using energy dispersive spectroscopy showed that the layer of corrosion product is formed. Results of XRD analysis on corroded specimens at $50{ }^{\circ} \mathrm{C}$ during 24 hours, showed that the corrosion product film consists of iron sulfide (FeS). The surface morphology of these specimens shows the occurrence of pitting attack.

Keywords: rotating speed, corrosion, carbon steel, EIS, $\mathrm{H}_{2} \mathrm{~S}$. 


\section{PENDAHULUAN}

Pipa untuk mengalirkan minyak dan gas mentah pada umumnya terbuat dari baja. Baja karbon jenis API 5LX65 merupakan baja yang diproduksi khusus untuk digunakan sebagai bahan pipa aliran fluida minyak bumi dan gas alam mentah [1]. Sektor minyak dan gas masih menjadi andalan sebagai penghasil devisa negara. Total potensi minyak bumi mentah yang telah terukur pada seluruh cekungancekungan hidrokarbon mencapai 86,9 milyar barrel atau 13,9 milyar $\mathrm{m}^{3}$ [2]. Sumur-sumur tua yang dahulu tidak dieksploitasi karena konsentrasi minyak dan gasnya rendah $(10 \%$ hingga 20\%) sekarang mulai dilirik kembali.

Akibat dari konsentrasi minyak dan gas yang rendah maka kandungan air, ion-ion sulfida, asam-asam organik dan garam-garam klorida serta gas-gas terlarut seperti hydrogen sulfida $\left(\mathrm{H}_{2} \mathrm{~S}\right)$ dan karbon dioksida $\left(\mathrm{CO}_{2}\right)$ akan semakin meningkat. Konsentrasi gas $\mathrm{H}_{2} \mathrm{~S}$ terlarut dalam minyak dan gas mentah pada umumnya berada pada rentang 2,0 $\mathrm{mg} / \mathrm{L}$ hingga 18,0 mg/L [3], sedangkan Wolfe dan Baron (1997) melaporkan bahwa untuk instalasi pipa minyak dan gas, kondisi fluida disebut sour jika mengandung klorida $35.000 \mathrm{mg} / \mathrm{L}, \mathrm{H}_{2} \mathrm{~S}$ $1.200 \mathrm{mg} / \mathrm{L}$ dan $\mathrm{CO}_{2} 1.000 \mathrm{mg} / \mathrm{L}$ [4]. Gunaltun (1996) melaporkan sekitar $8 \%$ hingga 10\% kerusakan bagian dalam pipa baja karbon akibat gas $\mathrm{H}_{2} \mathrm{~S}$ terlarut di industri minyak dan gas [5]. Serangan dari ion-ion $\mathrm{H}^{+}, \mathrm{S}^{2-}$ dan $\mathrm{HS}^{-}$ yang terlarut dan bersinergi dengan ion klorida $\left(\mathrm{Cl}^{-}\right)$akan menimbulkan kerusakan pada pipa baja karbon tersebut. Hal ini disebabkan oleh ion $\mathrm{Cl}^{-}$yang mampu merusak lapisan pasif baik sulfida maupun oksida yang terbentuk pada permukaan logam. Hasil penelitian Quez-Ake et al. (2008), melaporkan bahwa lapisan produk korosi sulfida hanya sedikit terbentuk pada pemukaan baja karbon dalam larutan $\mathrm{HCl} 0.05$ $\mathrm{mol} / \mathrm{L}$ yang mengandung hidrogen sulfida 500 $\mathrm{mg} / \mathrm{L}[6]$.

Pengaruh laju putar telah dikembangkan oleh Arzola-Peralta (2006) menyatakan bahwa kondisi aliran yang dikendalikan oleh Rotating Cylinder Electrode (RCE) dalam wilayah aliran turbulen (100-5000 rpm) dapat mempengaruhi arus katodik yang terukur [7]. Arus katodik tersebut dipengaruh oleh difusi senyawa akibat pengaruhi laju putar, sehingga berkontribusi terhadap rapat arus katodik yang akhirnya berpengaruh terhadap laju korosi.
Berdasarkan hasil-hasil penelitian tersebut, terbukti bahwa parameter-parameter seperti konsentrasi, laju alir, $\mathrm{pH}$ lingkungan dan suhu, dapat mempengaruhi laju korosi bagian dalam pipa baja karbon, sehingga dapat berkontribusi terhadap umur pakai pipa.

Oleh sebab itu, penelitian ini dimaksudkan untuk mengetahui pengaruh laju putar terhadap laju korosi baja karbon API 5LX65 di dalam larutan natrium klorida $(\mathrm{NaCl})$ yang mengandung $\mathrm{H}_{2} \mathrm{~S}$ terlarut

\section{BAHAN DAN METODE}

Spesimen dibuat dari pelat baja karbon API 5LX65 untuk uji korosi dengan metode EIS menurut standar ASTM:G59-91 [8], dengan dimensi $1,2 \mathrm{~mm} \times 1,0 \mathrm{~mm} \times 4 \mathrm{~mm}$. Spesimen dihubungkan dengan kabel tembaga dengan solder. Kemudian spesimen di mounting dengan resin epoxy membentuk lingkaran dengan diameter $40 \mathrm{~mm}$. Permukaan spesimen digosok dengan mesin poles mengunakan kertas abrasif dengan grit 120, 300, 600, 1000 secara bertahap. Spesimen dibersihkan dengan air destilasi kemudian dibilas dengan aseton/alkohol kemudian dikeringkan dan disimpan dalam desikator selama 24 jam.

Prosedur percobaan dimulai dengan mengukur luas permukaan, kemudian spesimen dimasukkan ke dalam sel korosi dengan permukaan berhadapan dengan elektroda referensi. Tutup sel korosi, spesimen dihubungkan dengan Gamry-instrument melalui working electrode. Elektroda standar Ag/AgCl dan logam Ag dimasukkan pada sel korosi dan dihubungkan dengan Gamryinstrument melalui reference electrode dan counter electrode, dan dimasukkan larutan uji. Gas $\mathrm{N}_{2}$ dialirkan untuk mendesak udara keluar selama 3 menit, kemudian gas $\mathrm{H}_{2} \mathrm{~S}$ dialirkan, dan set suhu uji dan laju putar. Gejala-gejala yang terjadi pada permukaan spesimen dicatat. Pengukuran dilakukan dengan program Gamry untuk metode EIS (Electrochemical Impedance Spectroscopy) dan OCP (Open Circuit Potential) selama 3 jam, dengan pengulangan 1 jam, 2 jam dan 3 jam. Pengukuran pada potensial sirkuit terbuka menggunakan arus bolak-balik beramplitudo $0,5 \mathrm{~V}$ dengan frekuensi $100 \mathrm{kHz}$ sampai $100 \mathrm{MHz}$. Setelah berhenti, tutup saluran gas $\mathrm{H}_{2} \mathrm{~S}$, kemudian angkat spesimen uji dan bersihkan dengan air 
kemudian keringkan dan simpan dalam desikator. Kemudian $\mathrm{pH}$ larutan setelah proses korosi dicatat. Prosedur ini dilakukan untuk ketiga variasi laju putar (50 rpm, $150 \mathrm{rpm}$ dan 250 rpm).

Analisis spesimen dilakukan dengan Scanning Electron Microscope (SEM), Energy Dispersive Spectroscopy (EDS) dan X-Ray Diffractomer $(X R D)$.

\section{HASIL DAN PEMBAHASAN}

\section{Pengaruh Laju Putar Terhadap Laju Korosi}

Hasil percobaan diperlihatkan pada Gambar 1. Gambar 1 memperlihatkan kurva Nyquist baja karbon API 5LX65 yang direndam dalam larutan $\mathrm{NaCl} 3,5 \%$ yang mengandung $500 \mathrm{mg} / \mathrm{L} \mathrm{H}_{2} \mathrm{~S}$ selama 3 jam dengan variasi laju putar $50 \mathrm{rpm}, 150 \mathrm{rpm}$, dan $250 \mathrm{rpm}$ pada $\mathrm{pH} 4$ dan suhu $50^{\circ} \mathrm{C}$. Pada Gambar 1 ini terlihat bahwa pergeseran dan penyempitan kurva setengah lingkaran impedansi imaginer terhadap impedansi real, dengan meningkatnya laju putar dari $50 \mathrm{rpm}$ sampai dengan 250 rpm. Hal ini mengindikasikan bahwa aktifitas pelarutan baja meningkat dengan percepatan laju putar. Hasil analisis semua kurva Nyquist pada Gambar 1 menggunakan Software Echem Analyst dari produk Gamry [9], ditunjukkan pada Tabel 1.

Tabel 1 menunjukkan nilai tahanan polarisasi $\left(\mathrm{R}_{\mathrm{p}}\right)$ semakin menurun dengan meningkatnya laju putar, sementara nilai tahanan larutan $\left(\mathrm{R}_{\mathrm{s}}\right)$ relatif tidak berubah. Hal ini menunjukkan bahwa peningkatan laju putar tidak meningkatkan disosiasi $\mathrm{H}_{2} \mathrm{~S}$ dalam larutan, tetapi mengurangi tebal diffusion layer sehingga juga mengurangi hambatan reaksi baja dengan lingkungan. Selain itu, peningkatan laju putar dari 50 ke 250 rpm memberikan pengaruh terhadap pelarutan kembali produk korosi (Quez-Ake et al., 2008) [6], sehingga suplai ion $\mathrm{H}^{+}$ke permukaan baja tidak terhalangi oleh produk korosi. Peningkatan laju putar memberikan pengaruh terhadap pemecahan gelembung udara yang menempel pada permukaan baja, dimana fenomena tersebut terlihat saat pengamatan percobaan dilakukan. Akibatnya, peningkatan laju putar akan meningkatkan rapat arus korosi $\left(\mathrm{i}_{\text {cor }}\right.$ ) dan laju korosi.

Selain itu, Tabel 1 menunjukkan bahwa nilai Cdl meningkat dengan meningkatnya laju putar. Hal ini dapat dijelaskan dengan peningkatan suplai ion $\mathrm{H}^{+}$ke permukaan logam akibat peningkatan laju putar sehingga menarik elektron lebih banyak dan meningkatkan pelarutan baja. Oleh sebab itu, muatan listrik pada permukaan logam meningkat dan Cdl meningkat, karena harga kapasitansi berbading lurus dengan muatan listrik dan berbanding terbalik dengan potensial (Bard, 1980) [10].

Pada laju putar yang sama dan waktu perendaman berbeda, terbukti bahwa semakin lama waktu perendaman, laju korosi semakin menurun seperti terlihat pada Gambar 2. Hal ini berkaitan pada waktu perendaman satu jam pertama permukaan logam masih belum terselimuti lapisan produk korosi sehingga laju korosi baja masih tinggi. Sedangkan pada waktu perendaman 2 sampai dengan 3 jam mulai terbentuk lapisan produk korosi pada permukaan baja dan belum terjadi pelarutan kembali, sehingga memperlambat laju korosi (Lucio-Garcia et al., 2009) [11].

Pengaruh laju putar terhadap proses korosi baja karbon dalam lingkungan klorida juga telah dipelajari dengan menggunakan metode tegangan rangkaian terbuka (OCP). Gambar 3. menunjukan kurva potensial korosi terhadap waktu perendaman selama waktu tertentu dengan variasi laju putar. Pada Gambar 3 tersebut terlihat bahwa potensial korosi pada laju putar $50 \mathrm{rpm}, 150 \mathrm{rpm}$ dan 250 rpm stabil pada $-517 \mathrm{mV}$ hingga $-508 \mathrm{mV}$ terhadap $\mathrm{Ag} / \mathrm{AgCl}$. Dengan demikian dapat dikatakan bahwa laju putar kurang berpengaruh terhadap potensial korosi. Berdasarkan data tersebut dapat diprediksi terjadi pelarutan $\mathrm{Fe}$ pada antarmuka logam-larutan, karena semua nilai potensial korosi tersebut masih berada di atas nilai potensial standar untuk baja yakni $444 \mathrm{mV}$ terhadap SHE. Apabila data nilai potensial tersebut diplot-kan pada diagram Pourbaix Fe-S- $\mathrm{H}_{2} \mathrm{O}$ [12] dengan nilai $\mathrm{pH} 4$, maka akan masuk pada daerah korosi dan diyakini terjadi pelarutan baja.

\section{Analisis Morfologi Permukaan}

Difraktogram hasil pengukuran XRD menunjukkan bahwa lapisan produk korosi terdiri dari mackinawite (FeS) seperti yang dapat dilihat pada Gambar 4. Lapisan ini bersifat protektif sehingga dapat menurunkan laju korosi baja sesaat sebelum mengalami pelarutan kembali akibat adanya ion klorida. Hasil analisis EDS juga mendukung fakta terbentuknya $\mathrm{FeS}$ yang ditandai oleh 
bertambahnya kandungan sulfur pada permukaan baja serta kandungan Fe turun dari 95,55\% berat menjadi 90,05\% berat (Gambar 5). Hal ini menunjukkan bahwa terjadi pelarutan $\mathrm{Fe}$ selama proses korosi dan membentuk sulfida seperti terlihat pada hasil XRD (Gambar 4). Pada Gambar 5(a) terlihat bahwa terdapat sulfur pada permukaan baja karbon yang telah mengalami proses korosi, hal ini membuktikan bahwa FeS telah terbentuk. Sedangkan morfologi permukaan dari hasil citra SEM (Gambar 5(b)) menunjukkan bahwa lapisan hasil korosi FeS mengalami proses pelarutan sehingga dapat membentuk korosi sumuran, sedangkan pada spesimen yang belum mengalami korosi, nampak permukaannya relatif rata karena lapisan hasil korosi tidak terbentuk.

\section{Mekanisme Korosi Akibat $\mathrm{H}_{2} \mathrm{~S}$}

Reaksi yang terjadi ketika terdapat $\mathrm{H}_{2} \mathrm{~S}$ dalam sistem adalah sebagai berikut [13]:

$$
\mathrm{H}_{2} \mathrm{~S}_{(\mathrm{g})} \rightleftarrows \mathrm{H}_{2} \mathrm{~S}_{(\mathrm{l})}
$$

Reaksi disosiasi yang terjadi dari $\mathrm{H}_{2} \mathrm{~S}$ terlarut adalah sebagai berikut [14]:

$$
\begin{aligned}
& \mathrm{H}_{2} \mathrm{~S}_{(\mathrm{aq})} \rightarrow \mathrm{H}^{+-}{ }_{(\mathrm{qq})}+\mathrm{HS}_{(\mathrm{aq})}^{-} \\
& \mathrm{HS}^{-}{ }_{(\mathrm{aq})} \rightarrow \mathrm{H}^{+-}{ }_{(\mathrm{aq})}+\mathrm{S}^{2-}{ }_{(\mathrm{aq})}
\end{aligned}
$$

Oleh sebab itu, reduksi ion hidrogen atau evolusi hidrogen diasumsikan sebagai reaksi katodik yang paling dominan dalam korosi oleh $\mathrm{H}_{2} \mathrm{~S}$.

Sebuah kemungkinan mekanisme pelarutan besi dalam larutan encer yang mengandung $\mathrm{H}_{2} \mathrm{~S}$ terlarut telah diusulkan oleh Ma et al. (2000) sebagai berikut [13]:

$$
\begin{aligned}
& \mathrm{Fe}+\mathrm{H}_{2} \mathrm{~S}+\mathrm{H}_{2} \mathrm{O} \rightleftarrows \mathrm{FeSH}_{\text {ads }}^{-}+\mathrm{H}_{2} \mathrm{O}^{+} \\
& \mathrm{FeSH}_{\text {ads }} \rightleftarrows \mathrm{Fe}(\mathrm{SH})_{\mathrm{ads}}+\mathrm{e}^{-} \\
& \mathrm{Fe}(\mathrm{SH})_{\mathrm{ads}} \rightarrow \mathrm{FeSH}^{+}+\mathrm{e}^{-}
\end{aligned}
$$

Spesi $\mathrm{FeSH}^{+}$pada permukaan elektroda dapat tergabung secara langsung kedalam lapisan yang tumbuh dari mackinawite (Shoesmith et al., 1980) menurut reaksi sebagai berikut [15]:

$$
\mathrm{FeSH}^{+} \rightarrow \mathrm{FeS}_{(1-\mathrm{x})}+\mathrm{xSH}^{-}+(1-\mathrm{x}) \mathrm{H}^{+}
$$

Atau spesi $\mathrm{FeSH}+$ akan terhidrolisis menjadi $\mathrm{Fe}^{2+}$ tergantung pada $\mathrm{pH}$ larutan (Ma et al., 2000), melalui reaksi [9]:

$$
\mathrm{FeSH}^{+}+\mathrm{H}_{2} \mathrm{O}^{+} \rightarrow \mathrm{Fe}^{2+}+\mathrm{H}_{2} \mathrm{~S}+\mathrm{H}_{2} \mathrm{O}
$$

Jika reaksi (7) menghasilkan $\mathrm{FeS}(1-\mathrm{x})$ yang lewat jenuh namun tidak merata pada seluruh permukaan elektroda, maka akan terjadi pembentukan inti dan penumbuhan satu atau lebih besi sulfida seperti mackinawite dan troilite. $\mathrm{H}_{2} \mathrm{~S}$ mulai berperan sebagai inhibitor dengan terbentuknya mackinawite melalui reaksi (7). Mackinawite dapat berubah menjadi troilite atau sulfida jenis lain yang bervariasi sifat protektifnya.

Berdasarkan hasil penelitian ini dan didukung oleh hasil penelitian sebelumnya dapat disimpulkan bahwa mekanisme korosi baja karbon dalam lingkungan klorida yang mengandung $\mathrm{H}_{2} \mathrm{~S}$ terlarut dimulai oleh reaksi disosiasi $\mathrm{H}_{2} \mathrm{~S}$ menjadi $\mathrm{H}^{+}$dan $\mathrm{HS}^{-}$. Hal ini dapat dijelaskan dengan data percobaan yang memperlihatkan terjadinya penurunan $\mathrm{pH}$ yang relatif kecil selama proses korosi berlangsung. Kemudian, ion hidrogen $\left(\mathrm{H}^{+}\right)$hasil disosiasi $\mathrm{H}_{2} \mathrm{~S}$ terlarut akan mengoksidasi besi (Fe) menjadi ion $\mathrm{Fe}^{2+}$. Selanjutnya $\mathrm{Fe}^{2+}$ bereaksi dengan $\mathrm{HS}^{-}$menghasilkan $\mathrm{FeSH}^{+}$yang kemudian membentuk besi sulfida FeS. Rentang $\mathrm{pH}$ yang diperoleh dengan variasi konsentrasi $\mathrm{H}_{2} \mathrm{~S}$ selama percobaan adalah 3,4 hingga 4,1. Hal ini sesuai dengan hasil penelitian sebelumnya yang menyatakan bahwa FeS terbentuk pada rentang $\mathrm{pH}$ antara 3,0 hingga 5,0 dengan konsentrasi $\mathrm{H}_{2} \mathrm{~S}$ rendah.

\section{KESIMPULAN}

Berdasarkan data hasil percobaan dan pembahasan dapat disimpulkan bahwa :

1. Hasil pengukuran EIS pada baja karbon API 5LX65 yang direndam dalam larutan $\mathrm{NaCl}$ 3,5\%, pH 4 selama 3 jam pada suhu $50^{\circ} \mathrm{C}$ dengan variasi laju putar $50 \mathrm{rpm}, 150$ rpm, dan 250 rpm menunjukkan bahwa nilai $\mathrm{R}_{\mathrm{p}}$ menurun dengan meningkatnya laju putar, sementara nilai $R_{s}$ relatif tidak berubah.

2. Nilai $\mathrm{C}_{\mathrm{dl}}$ meningkat dengan meningkatnya laju putar. Hal ini mengindikasikan bahwa peningkatan laju putar tidak meningkatkan disosiasi $\mathrm{H}_{2} \mathrm{~S}$ dalam larutan, tetapi mengurangi tebal diffusion layer sehingga juga mengurangi hambatan reaksi baja dengan lingkungan.

3. Rapat arus korosi $\left(i_{\text {cor }}\right)$ dan laju korosi baja karbon meningkat dengan meningkatnya laju putar dari 50 rpm hingga $250 \mathrm{rpm}$.

4. Pada laju putar yang konstan, terbukti bahwa semakin lama waktu perendaman laju korosi baja semakin menurun. 
5. Hasil analisis XRD menunjukkan bahwa lapisan hasil korosi yang terbentuk pada permukaan spesimen uji adalah mackinawite (FeS).

6. Hasil analisis EDS menunjukkan bahwa lapisan hasil korosi FeS terbentuk pada permukaan baja yang ditandai oleh bertambahnya kandungan sulfur serta kandungan $\mathrm{Fe}$ turun dari 95,55\% berat menjadi $90,05 \%$ berat.

7. Hasil citra SEM menunjukkan terjadinya korosi sumuran pada permukaan baja karbon API 5LX65 yang direndam selama 24 jam dalam larutan $\mathrm{NaCl} 3,5 \%$ yang mengandung $\mathrm{H}_{2} \mathrm{~S} 500 \mathrm{mg} / \mathrm{L}$ pada $\mathrm{pH} 4$.

\section{UCAPAN TERIMA KASIH}

Penulis mengucapkan terimakasih kepada Prof. Dr. Rolf Gubner yang telah mengijinkan pemakaian Gamry Potensiostate di Lab. Korosi Curtin University of Technology, Australia.

\section{DAFTAR PUSTAKA}

[1] Djaka T, Koswara, Antarikso C, dan Muslim Z.A, 2004, "Disain dan Pembuatan Baja Lembaran Panas sebagai Bahan Baku Minyak dan Gas”, Proceeding of Indonesian Pipeline Technology, ITB, Bandung.

[2] Lubis, S., 2007, "Potensi Energi Minyak dan Gas berada di Cekungan Tersier", Berita Departemen Pertambangan Indonesia, Jakarta.

[3] Van, Ng.V, Toai, T.V., and Son, Ng. V., 2006, "Study on Corrosive Ability of Oil Gas in Bachho Vietnam to Carbon Steel and Protection of Pipeline by Inhibitors" , Korosi \& Material, Indocor, Indonesia, VI, No. 4 : 8-11.

[4] Wolfe and Baron, 1997, "Flexible pipe combats corrosion threat at sour brine injection site", Oil and gas Journal, No.95 : 48 - 51 .

[5] Gunaltum, 1996," CO2 and H2S Corrosion in Oil and Gas Production System", Proceeding of One Day Seminar, Total Indonesie, ITB, Bandung, 4-6.

[6] Quez-Ake, J., Sierra, R.C., Estrada, E.A., and Cruz, M.J., 2008, "EIS Evaluation of the Effect of Neutralizing and Inhibitor
Compounds on Corrosion Process of 1018 Carbon Steel in Acid Solution Typical of Atmospheric Distillation Plants”, Int. J. Electrochem. Sci., 3, : 56 66.

[7] Arzola-Peralta, Mendoza-Flores, DuranRomero, and, Genesca, 2006, "Cathodic kinetics of API X70 pipeline steel corrosion in $\mathrm{H}_{2} \mathrm{~S}$ containing solutions under turbulent flow conditions”, Journal of Corrosion Engineering, Science and Technology, Vol41, No. 4, 321-327.

[8] ASTM G-59, 1991, "Standard Practice for Conducting Potentiodynamic Polarization Resistance measurement”, American Society for Testing and Material

[9] Gamry, 2008, "Echem Analysist Software”, Bioanalytical System, Inc. Gamry-Instrument, USA.

[10] Bard, A.J., 1980, "Electrochemical Methods Fundamentals and Applications”, John Wiley \& Sons, Inc., Canada, p.327.

[11] Lucio-Garcia, M.A., Gonjalez, J.G., Casales, M., Martinez, L., Chacon J.G., Neri, M.A., and Martinez, A., 2009, "Effect of heat treatment on H2S corrosion of a micro-alloyed C-Mn steel”, J. of Corrosion Science, 51 : 2380-2386.

[12] Ogundele, G.I., and White, W.E., 1986, "Some Observations on The Corrosion of Carbon Steel in Sour Gas Environment”, Journal of CorrosionNACE, 42, No.7, 398 - 407.

[13] Ma H.Y., Cheng X.L., Chen S.H., Li G.Q., Chen X., Lei S. B., and Yang H.Q., 2000, “The Influence of Hydrogen Sulfide on Corrosion of Iron under Different Condition”, Corrosion Science, 42, p. 1669.

[14] Parakala, S.R., 2005, "EIS Investigation of $\mathrm{CO} 2$ and H2S Corrosion under Film Forming Conditions", Thesis, Ohio University : 19 - 20.

[15] Shoesmith D.W, Taylor P., Bailey M.G., and Owen D.G., 1980," The Formation of Ferrous Monosulfide Polymorphs during the Corrosion of Iron by Aqueous Hydrogen Sulfide at 210C”, Journal of Electrochem. Soc, 127, 1007. 


\section{Lampiran}

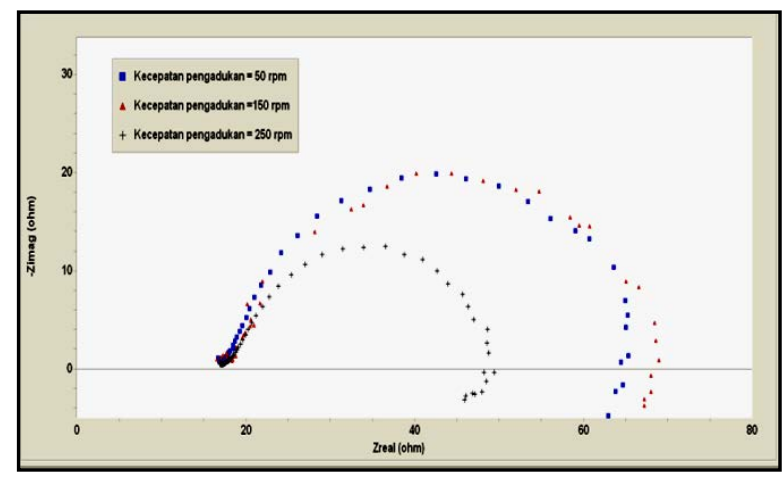

Gambar 1. Kurva Nyquist Baja Karbon API 5LX65 dengan Variasi Laju Putar 50 rpm, $150 \mathrm{rpm}$, dan $250 \mathrm{rpm}$

Tabel 1. Parameter Elektrokimia dari Hasil Pengukuran EIS pada Baja Karbon API 5LX65 dengan Variasi Laju Putar 50 rpm, 150 rpm, 250 rpm

\begin{tabular}{cccccc}
\hline $\begin{array}{c}\text { Kecepatan } \\
\text { pengadukan } \\
(\mathrm{rpm})\end{array}$ & $\begin{array}{c}\mathrm{R}_{\mathrm{s}} \\
(\mathrm{ohm})\end{array}$ & $\begin{array}{c}\mathrm{R}_{\mathrm{p}} \\
(\mathrm{ohm})\end{array}$ & $\begin{array}{c}\mathrm{C}_{\mathrm{dl}} \\
\left(\text { Farad) } \times 10^{-6}\right.\end{array}$ & $\begin{array}{c}\mathrm{i}_{\text {cor }} \\
\left(\mu \mathrm{A} / \mathrm{cm}^{2}\right)\end{array}$ & $\begin{array}{c}\text { Laju korosi } \\
(\mathrm{mm} / \mathrm{th})\end{array}$ \\
\hline 50 & 21,21 & 54,52 & 240,80 & 15,31 & 0,18 \\
\hline 150 & 18,47 & 47,32 & 348,50 & 17,64 & 0,20 \\
\hline 250 & 18,49 & 29,29 & 444,41 & 28,50 & 0,33 \\
\hline
\end{tabular}

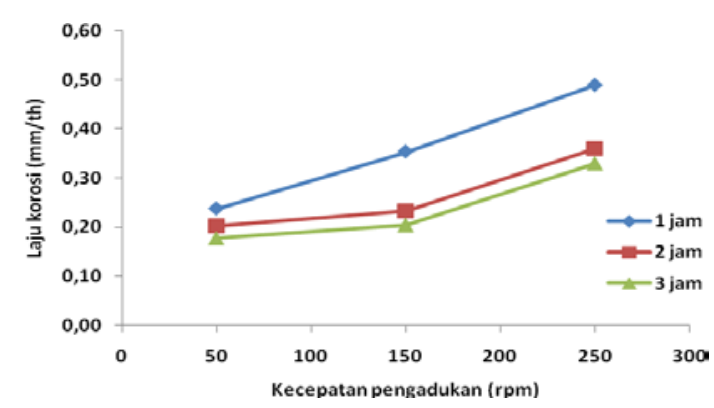

Gambar 2. Kurva Laju Korosi terhadap Laju Putar untuk Baja Karbon API 5LX65 Selama 1 sampai

3 jam dengan Variasi Laju Putar 50 rpm, 150 rpm, 250 rpm

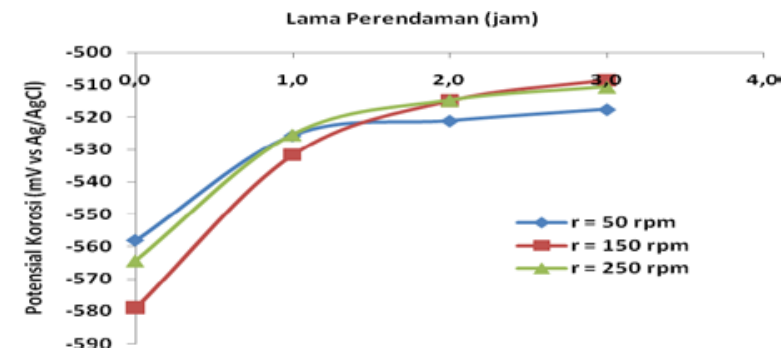

Gambar 3. Kurva Potensial Korosi terhadap Waktu untuk Baja Karbon API 5LX65 Selama 1 sampai 3 jam dengan Variasi Laju Putar 50 rpm, 150 rpm, 250 rpm 

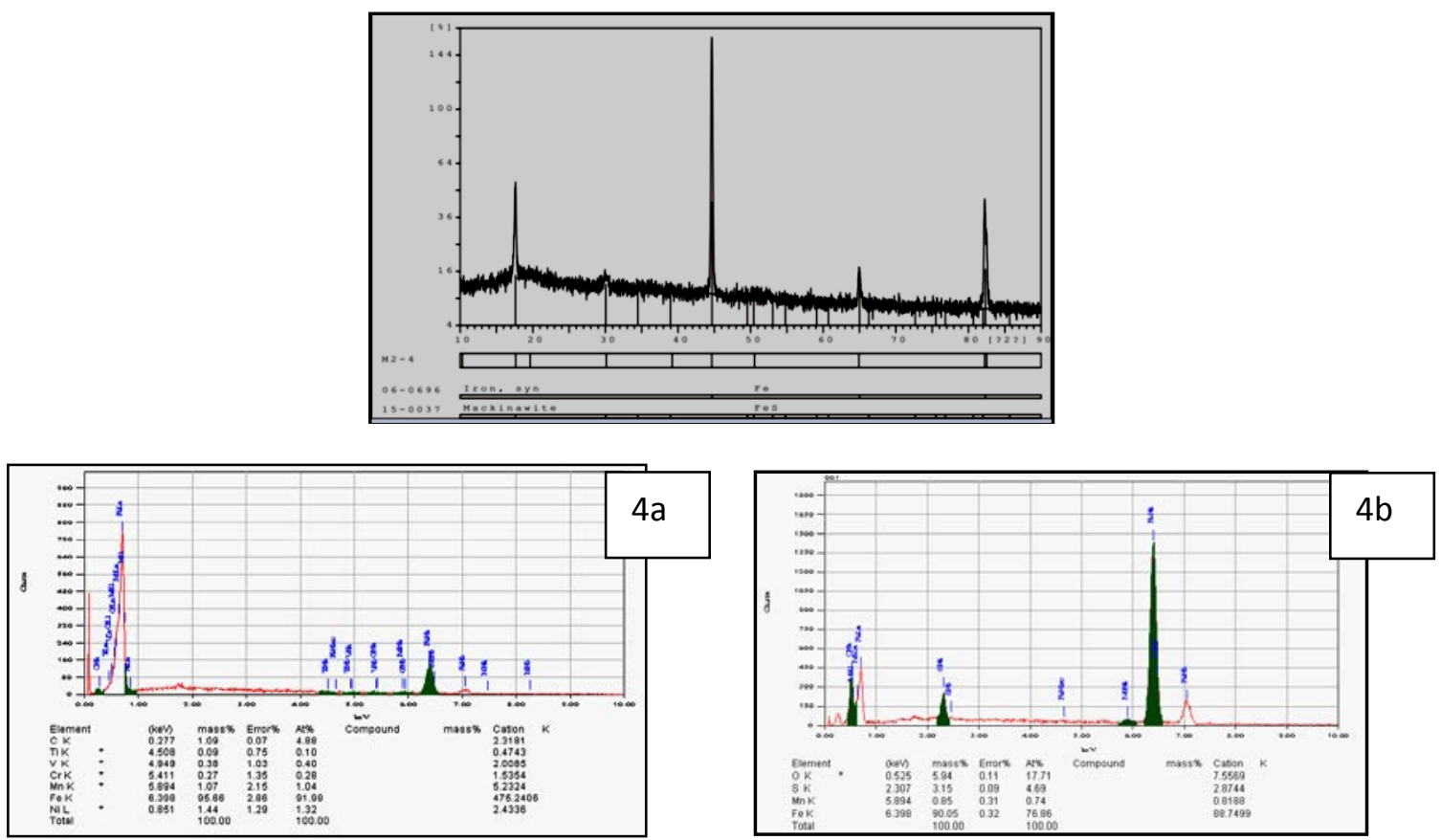

Gambar 4. Difraktrogram XRD Baja Karbon API 5LX65 pada Suhu 50 C dan Laju Putar 50 rpm
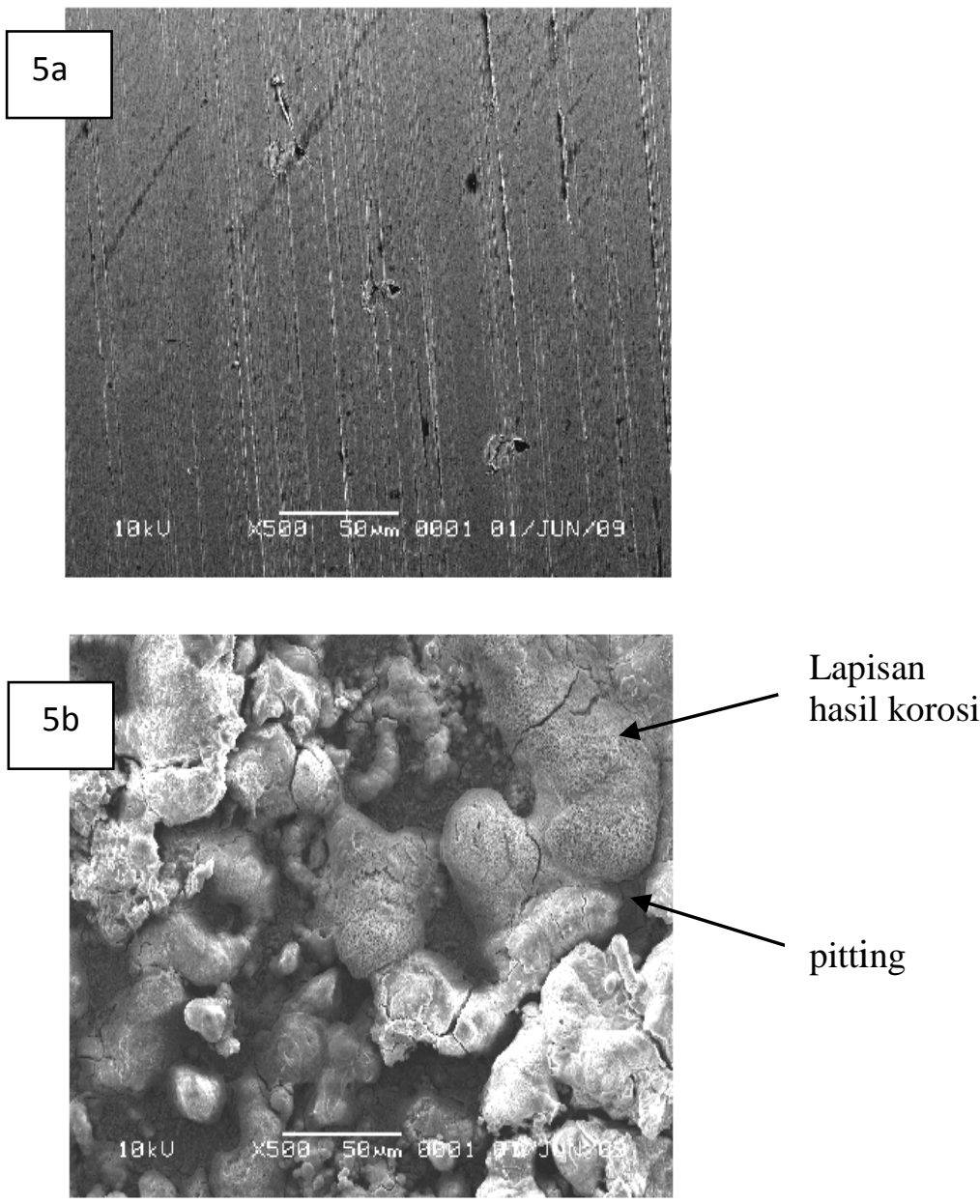

Gambar 5. Citra SEM Baja Karbon API 5LX65 (5a) sebelum Proses Korosi (5b) setelah Proses Korosi pada Suhu $50^{\circ} \mathrm{C}$ dan Laju Putar $50 \mathrm{rpm}$ 
Jurnal Teknologi Bahan dan Barang Teknik Vol. 2 No. 1, Juni 2012 : 1 - 8 